\title{
Perlindungan Terumbu Karang Menurut UNCLOS 1982 (Studi Kasus Kerusakan Terumbu Karang oleh Kapal Pesiar M.V. Caledonian Sky di Raja Ampat)*
}

\author{
Maretta Trimirza*; Ramlan; Rahayu Repindowaty Harahap \\ Fakultas Hukum Universitas Jambi \\ *Coresponding author: marettatrimirza@gmail.com
}

$\begin{array}{ll}\text { Submission } & : \text { 4 November } 2020 \\ \text { Revision } & : \text { 5 November } 2020 \\ \text { Publication } & : \text { 18 Maret } 2021\end{array}$

\begin{abstract}
Coral reefs and all the life contained in them are one of the most valuable natural assets. Various damages done by humans have caused damage to the ecosystem that marine resources are reduced. The case of the collision by the cruise ship M.V. Caledonian Sky in Raja Ampat is causing damage to coral reefs, it needs protection and responsibility. This study aims to: First, identify and analyze how the protection of the marine environment against coral reefs is caused by the M.V. Cruise Ship. Caledonian Sky based on international law and national law. Second, knowing and analyzing how the M.V. Caledonian Sky for damage to coral reefs based on UNCLOS 1982 and national laws. The research method used is normative juridical research, by examining document studies using a variety of secondary data or library materials. The results of this study are First, protection of the marine environment against damage to coral reefs by the M.V. cruise ship. Caledonian Sky according to international law in accordance with UNCLOS 1982 article 194 paragraphs (1) and (2) concerning measures to prevent, reduce and control pollution of the marine environment. According to national laws protecting the marine environment against damage to coral reefs by the cruise ship M.V. Caledonian Sky is regulated in laws concerning the protection of the marine environment and applies in Indonesia. Second, Cruise Ship Legal Liability M.V. Caledonian Sky for Damage to Coral Reefs according to international law is regulated in UNCLOS 1982
\end{abstract}


Article 193 concerning the sovereign rights of the State to exploit its natural resources and Article 235 concerning responsibility and compensation obligations. According to national law, it is stipulated in laws concerning accountability and applies in Indonesia. Third, the London-based Noble Calidonia Company has acknowledged responsibility for this case. To prevent the occurrence by Caledonian Sky cruises, Indonesia must establish signs for certain areas to be used as shipping activities. Second, in upholding national law and international law in the supervision of marine waters in Indonesia, the government of the Republic of Indonesia must affirm and apply existing laws correctly and clearly in order to become a deterrent effect for ship operators and ship captains to prevent this kind of happening again in Indonesian marine. Third, in resolving cases of damage to coral reefs, Law Number 32 of 2009 concerning Environmental Protection and Management, Article 87 paragraphs (1) and (2) can be used.

Keywords: Coral Reefs; Marine Environmental Protection; UNCLOS 1982

\begin{abstract}
Abstrak
Terumbu karang dan segala kehidupan yang terdapat didalamnya merupakan salah satu kekayaan alam yang bernilai tinggi. Berbagai kerusakan yang dilakukan manusia menyebabkan kerusakan ekosistem sehigga sumber daya laut berkurang. Kasus penabrakan yang dilakukan kapal pesiar M.V. Caledonian Sky di Raja Ampat membuat kerusakan terumbu karang sehingga perlunya perlindungan dan pertanggujawaban. Penelitian ini bertujuan yaitu Pertama, mengetahui dan menganalisa bagaimana perlindungan lingkungan laut terhadap terumbu karang atas kerusakan yang dilakukan Kapal Persiar M.V. Caledonian Sky berdasarkan hukum internasional dan hukum nasional. Kedua, mengetahui dan menganalisa bagaimana pertanggungjawaban hukum kapal persiar M.V. Caledonian Sky atas kerusakan terumbu karang berdasarkan UNCLOS 1982 dan hukum nasional. Maka metode penelitian yang digunakan adalah penelitian yuridis normatif yaitu mengkaji studi dokumen yang menggunakan berbagai data sekunder atau bahan pustaka. Hasil penelitian ini adalah Pertama, Perlindungan lingkungan laut terhadap kerusakan terumbu karang yang dilakukan kapal pesiar M.V. Caledonian Sky menurut hukum internasional sesuai dengan UNCLOS 1982 pasal 194 ayat (1) dan (2) mengenai tindakan-tindakan untuk mencegah, mengurangi, dan mengendalikan pencemaran lingkungan laut. Menurut hukum nasional perlindungan lingkungan laut terhadap kerusakan terumbu karang yang dilakukan kapal pesiar M.V. Caledonian Sky diatur dalam perundang-undangan yang
\end{abstract}


mengenai perlindungan lingkungan laut serta berlaku di Indonesia. Kedua, Pertanggungjawaban Hukum Kapal Pesiar M.V. Caledonian Sky atas Kerusakan Terumbu Karang menurut hukum internasional diatur dalam UNCLOS 1982 Pasal 193 mengenai Hak kedaulatan Negara untuk mengeksploitasikan kekayaan alamnya dan Pasal 235 mengenai tanggung jawab dan kewajiban ganti rugi. Menurut hukum nasional diatur dalam perundang-undangan yang mengenai pertanggungjawaban serta berlaku di Indonesia. Ketiga, Perusahaan Noble Calidonia yang berbasis di London telah mengakui bertanggung jawab atas kasus ini. Diharapkan pertama, Untuk mencegah terjadinya kejadian seperti yang dialami oleh kapal pesiar Caledonian sky, Indonesia harus menetapkan tanda bagi kawasan-kawasan tertentu untuk digunakan sebagai kegiatan pelayaran. Kedua, Dalam menegakkan hukum nasional dan hukum internasional dalam pengawasan perairan laut di Indonesia, pemerintah Republik Indonesia harus menegaskan dan mengaplikasikan undang-undang yang telah ada secara benar dan jelas agar menjadi efek jera bagi pihak operator kapal dan kapten kapal agar mencegah hal seperti ini terjadi lagi di perairan laut Indonesia. Ketiga, Dalam penyelesaian kasus kerusakan terumbu karang ini dapat digunakannya Undang-Undang Nomor 32 Tahun 2009 Tentang Perlindungan dan Pengelolaan Lingkungan Hidup Pasal 87 ayat (1) dan (2).

Kata Kunci: Perlindungan Lingkungan Laut; Terumbu Karang; UNCLOS 1982

\section{A. Pendahuluan}

Indonesia sebagai negara maritim memanfaatkan fungsi laut secara maksimal. Fungsi laut dapat dibagi atas sebagai sumber makanan bagi umat manusia, sebagai jalan raya perdagangan, sebagai sarana untuk penaklukan, sebagai tempat pertempuran-pertempuran, sebagai tempat bersenang-senang dan rekreasi, sebagai alat pemisah dan pemersatu bangsa. ${ }^{1}$ Laut dapat digunakan oleh manusia sebagai sumber daya alam bagi penghidupannya, jalur lintas pelayaran, kepentingan pertahanan dan keamanan, dan kepentingan lainnya.

1 Didik Mohamad Sodik, Hukum Laut Internasional dan Pengaturannya di Indonesia, PT Refika Aditama, Bandung, 2014, hal. 1. 
Wilayah laut cenderung lebih besar dibumi jika dibandingkan dengan wilayah daratan terlihat dalam kondisi geografis bumi wilayah lautan menduduki $3 / 4$ atau sekitar $70 \%$ dari total wilayah permukaan bumi. Mengenai Wilayah laut sudah diatur oleh United Nations On The Law Of The Sea 1982, Maka dalam hal wilayah laut terdiri dari perairan pedalaman, laut teritorial, perairan negara kepulauan, zona tambahan, zona ekonomi eksklusif, landasan kontinen, laut bebas, Kawasan dasar laut teritorial. ${ }^{2}$

Terumbu Karang menjadi pondasi atau dasar bagi komunitas kehidupan laut yang dinamis dan amat beragam. Sedangkan karang merupakan sebagian makhluk pembentuk terumbu, selebihnya adalah organisme yang lain. Ekosistem terumbu karang mempunyai manfaat yang bermacam-macam, yaitu sebagai digunakan sebagai bahan obat-obatan, dimanfaatkan sebagai objek wisata bahari dan sebagai penahan gelombang untuk melindungi pantai dari bahaya abrasi.

John Nevill, sebagaimana dikutip oleh Emmy Latifah, menyatakan terdapat lima hal yang mengancam kehidupan dan keberlangsungan ekosistem perairan, yaitu: ${ }^{3}$

1. climate change as a result of rising carbon dioxide level at atmosphere, as well as impacts from damage to the ozone layer;

2. overfishing with attendant bycatch problems, both from industrial fishing, recreational fishing, illegal, unregulated, and unreported fishing (IUU), and ghost fishing;

2 Ririn Ardila dan Akbar Kurnia P, "Sengketa Wilayah Zona Ekonomi Eksklusif Indonesia (Studi Kasus Klaim Cina Atas Laut Natuna Utara)" Uti Possidetis: Journal of International Law, Vol. 01 No. 03, 2020, hal. 359.

3 Emmy Latifah dan Moch Najib Imanullah, "Applying Precautionary Principle in Fisheries Management", Jambe Law Journal, Vol. 01 No. 01, 2018, hal. 13-14. 
3. habitat damage, including destruction of coral reefs, mangroves, natural freshwater flows (and passage), coastal foreshores, coastal wetlands, which largely caused by fishing gear (bottom trawling);

4. pollution: including nutrients, sediments, plastic litter, noise, hazardous and radioactive substances; discarded fishing gear, microbial pollution, and trace chemicals such as carcinogens, endocrinedisruptors, and info-disruptors; dan

5. ecosystem alterations caused by the introduction of alien organisms, especially those transported by vessel ballast water and hull fouling.

Kerusakan (degradasi) ekosistem terumbu karang di Indonesia disebabkan oleh enam faktor utama, yaitu: penambangan karang (coral mining) untuk keperluan bahan bangunan, pembuatan jalan, dan bahan hiasan, penggunaan bahan peledak bom, bahan beracun, dan teknikteknik destruktif lainnya dalam aktivitas penangkapan ikan di kawasan terumbu karang, kegiatan wisata bahari yang kurang memperhatikan kelestarian sumber daya alam laut, pencemaran, baik yang berasal dari kegiatan-kegiatan ekonomi pembangunan di darat maupun di laut, sedimentasi akibat pengelolaan lahan atas (upland areas) yang tidak atau kurang mengindahkan kaidah-kaidah ekologis (pelestarian lingkungan), konservasi kawasan terumbu karang menjadi kawasan pemukiman, bisnis, industri dan lainnya melalui kegiatan reklamasi, seperti yang terjadi di manado, lampung dan pantai carita, dan sebab-sebab alamiah, termasuk pemanasan global yang telah mengakibatkan "coral bleaching" dan ledakan populasi binatang bulu seribu 
(acanthaster planci). ${ }^{4}$ Garis besar kerusakan ekosistem terumbu karang di laut Indonesia ada beberapa hal yang dilakukan nelayan atau hal-hal karena alam atau iklim global.

Berdasarkan hasil penelitian Pusat Penelitian Oseanografi Lembaga Kondisi kesehatan laut menurun diakibatkan oleh perubahan iklim di dunia. Peningkatan iklim akan meningkatkan keasaman air laut dimana terumbu karang, sebagai penyedia makanan, pekerjaan, dan melindungi ratusan juta manusia dari badai akan punah pada tahun 2050. Ilmu Pengetahuan Indonesia (LIPI) pada tahun 2015 menunjukkan bahwa ada 1.259 lokasi kawasan terumbu karang yang ada di Indonesia terdapat sekitar 30,02\% dalam kondisi kurang (tutupan karang hidup 0-24\%); 37,97\% mengalami kerusakan dengan kondisi cukup (tutupan karang hidup 25-49\%); 27,01\% masih dalam kondisi baik (tutupan karang hidup 50-74\%), dan hanya tinggal 5,00\% dalam kondisi sangat baik (tutupan karang hidup 75-10\%). Kerusakan terumbu karang paling parah terjadi di Indonesia bagian timur yaitu 40,29\% dalam kondisi kurang, upaya pemulihan perlu dilakukan untuk menanggulangi kerusakan lebih besar". ${ }^{5}$

Salah satu kasus pencemaran lingkungan laut yang terjadi yaitu, pada 3 Maret 2017 Indonesia diberitakan kejadian penabrakan terumbu karang di Raja Ampat yang dilakukan oleh kapal pesiar Caledonian Sky (Kapal Asing berbendera negara Bahama dan dimiliki perushaan tur operator Noble Caledonia yang berbasis di London, Inggris). Hasil dari investigasi awal pemerintah menunjukkan luas kerusakan terumbu karang

4 https://www.academia.edu/39097659/PELESTARIAN DAN PER LINDUNGAN PADA TERUMBU KARANG, diakses pada Hari Selasa Tanggal 18 Februari Tahun 2020 pada Pukul 23.06 WIB.

5 Tasia Masyitah, "Pertanggung Jawaban Kapal Caledonian Sky Atas Kerusakan Terumbu Karang Yang Berada Di Raja Ampat", Skripsi Sarjana Hukum Universitas Sumatra Utara (USU), Medan, 2018, hal. 18-19. 
kurang lebih mencapai 1,8 hektar. Kawasan daerah terjadinya penabrakan kapal asing merupakan zona pemanfaatan terbatas kawasan konservasi perairan Selat Dampier daerah Kepulauan Raja Ampat yang ditetapkan oleh Menteri Kelautan dan Perikanan No 36/KEPME-KP/2014 tentang Penetapan Taman Wisata Perairan Kepulauan Raja Ampat.

Kapal kandas saat melakukan tur pengamatan burung di Pulau Waigeo, kapal diduga kandas akibat nahkoda hanya memonitor Global Positioning System (GPS) dan radar tanpa memperhitungkan pasang surut air laut. Kapal akhirnya terjebak di perairan dangkal dan baru bisa ditarik keluar setelah air kembali naik. Rusaknya ekosistem terumbu karang yang diakibatkan kapal persiar dapat terjadi karena kapal masuk ke perairan dangkal, dikarenakan Human Eror atau nakoda yang membawa kapal bergeser dari rute yang seharusnya sejauh setengah mil dan nakoda yang tidak memperhatikan navigasi untuk alur laut kepulauan dan faktor alam yaitu pasang surutnya air laut.

Raja Ampat ditetapkan sebagai Kawasan Konservasi Perairan Nasional (KKPN) karena memiliki keanekaragaman sumber daya alam yang tinggi berupa terumbu karang, mangrove, litoral dan rumput laut. Wilayah ini terletak di "jantung" kekayaan terumbu karang dunia yang dikenal dengan sebutan Segitiga Karang/Coral Triangle. Kawasan Konservasi Perairan Nasional (KKPN) di Raja Ampat ini merupakan salah satu kawasan yang memiliki fauna ikan karang terkaya di dunia yang terdiri dari paling sedikit 1,074 spesies serta merupakan areal pembesaran bagi sebagian besar jenis penyu yang terancam punah. ${ }^{6}$

6 http://kkji.kp3k.kkp.go.id/index.php/basisdata-kawasan konser vasi/details/1/64\#: :text=Raja $\% 20 \mathrm{Ampat} \% 20$ ditetapkan $\% 20$ se bagai $\% 20$ Kawasan,sebutan $\% 20$ Segitiga $\% 20$ Karang\%2FCoral $\% 2$ 0Triangle., diakses pada Hari Jumat Tanggal 5 Juni Tahun 2020 pada pukul 02.07 WIB.

Uti Possidetis: Journal of International Law, Vol. 1, No. 2 (2020) 
Kerusakan terumbu karang yang dilakukan kapal pesiar M.V. Caledonian Sky menyebabkan kerugian yang cukup besar dialami dalam penabrakan kapal-kapal di perairan Indonesia. Ketentuan dalam UNCOLS 1982, negara wajib bertanggung jawab untuk pemenuhan kewajiban-kewajiban internasional mereka berkenaan dengan perlindungan dan pelestarian lingkungan laut, maka Indonesia melakukan dan menindak atas kerusakan terumbu karang sebagai tanggung jawab yang dilakukan negara berdasarkan ketetentuan dalam UNCLOS 1982 dan hukum nasionalnya.

Perlindungan terhadap lingkungan laut khususnya terumbu karang yang diperlukan karena sebagai tempat tinggal biota laut dan sumber daya alam bagi Negara Indonesia. Maka dari masalah diatas penulis mengangkat judul penelitian tentang "Analisis Hukum Perlindungan Lingkungan Laut Terhadap Terumbu Karang Menurut UNCLOS 1982 (Studi Kasus Kerusakan Terumbu Karang Yang Dilakukan Kapal Pesiar M.V. Caledonian Sky Di Raja Ampat)".

\section{B. Pembahasan dan Analisis}

1. Perlindungan Lingkungan Laut Terhadap Terumbu Karang atas Kerusakan yang Dilakukan Kapal Persiar M.V. Caledonian Sky Berdasarkan UNCLOS 1982 dan Hukum Nasional

Kementerian Koordinator Bidang Kemaritiman menjelaskan perkembangan penyelesaian insiden rusaknya terumbu karang di Raja Ampat, Papua Barat, akibat kandasnya kapal pesiar MV Caledonian Sky. Kerusakan terumbu karang di Raja Ampat, Papua Barat, seluas lebih dari 13.533 meter persegi akibat ditabrak kapal pesiar Caledonian Sky pada 4 Maret lalu. Kapal pesiar Caledonian Sky yang ketika berlayar menggunakan bendera Bahama adalah kapal milik dan dioperasikan oleh Swedia, namun pembelian tiket atau operasi juga dilakukan di Inggris. Kapten kapal Keith Michael Taylor 
adalah warga negara Inggris yang tinggal di Amerika. Terumbu karang yang rusak itu berada tepat di jantung Raja Ampat, sebuah pusat keanekaragaman hayati laut. Kerugian akibat terumbu karang yang rusak itu adalah ikan yang hilang, biota yang mati, ekosistem dan pariwisata.

Kapten Keith Michael Taylor sebelumnya diketahui sudah pernah melakukan pelanggaran serupa di pelabuhan Kuala Tanjung - Sumatera Utara. Dia menjelaskan bahwa kapten kapalnya adalah warga negara Inggris tetapi tinggal di Amerika. Direktur Jenderal Pengelolaan Ruang Laut (PRL) Kementerian Kelautan dan Perikanan mengatakan pemerintah akan segera mengajukan gugatan hukum terhadap kaptennya. Akibat tragedi kandasnya Kapal Caledonian Sky yang menghantam terumbu karang di Raja Ampat, Papua Barat, sektor pariwisata di kawasan konservasi dan ekowisata tersebut diperkirakan bakal terkena dampaknya.

Deputi Koordinasi Bidang Kedaulatan Maritim Kemenko Kemaritiman mengatakan bahwa jumlah $18.882 \mathrm{~m}^{2}$ itu dibagi menjadi dua gradasi kerusakan yang berbeda,13.270 $\mathrm{m}^{2}$ mengalami rusak total oleh kapal dan $5.612 \mathrm{~m}^{2}$ rusak sedang akibat hempasan pasir dan pecahan terumbu karang karena olah gerak kapal, namun terumbu karang yang rusak sedang itu mempunyai tingkat harapan hidup hanya tinggal 50 persen dan menjelaskan laporan tim teknis yang kini masih berada di Raja Ampat. $^{7}$

\section{a. Berdasarkan Hukum Internasional (UNCLOS 1982)}

Pasal 145 dalam UNCLOS 1982 mengenai Perlindungan Lingkungan Laut menjelaskan bahwa:

7 https://www.voaindonesia.com/a/insiden-di-raja-ampat-indone sia-akan-minta-pertanggungjawaban-semua-pihak/3775111.htm l, diakses pada Hari Selasa Tanggal 4 Agustus 2020 pada Pukul 19.53 WIB. 
"Tindakan-tindakan yang perlu berkenaan dengan kegiatan-kegiatan di Kawasan harus diambil sesuai dengan konvensi ini untuk menjamin perlindungan yang efektif terhadap lingkungan laut dari akibat-akibat yang merugikan yang mungkin timbul dari kegiatan-kegiatan tersebut. Untuk tujuan ini Otorita harus menetapkan ketentuan-ketentuan, peraturan-peraturan dan prosedur-prosedur yang tepat untuk inter alia: (a) pencegahan, pengurangan dan pengendalian pencemaran dan bahaya-bahaya lainnya terhadap lingkungan laut, termasuk garis pantai, dan gangguan terhadap keseimbangan ekologis lingkungan laut, dengan memberikan perhatian khusus pada kebutuhan akan perlindungan terhadap akibat-akibat buruk dari kegiatan-kegiatan seperti pemboran, pengerukan, penggalian, pembuangan limbah, pembangunan dan operasi atau pemeliharaan instalasiinstalasi, saluransaluran pipa dan peralatan-peralatan lainnya yang bertalian dengan kegiatan-kegiatan itu dan (b) perlindungan dan konservasi kekayaan-kekayaan alam Kawasan dan pencegahan kerusakan terhadap flora dan fauna lingkungan laut." 8

Konvensi Pasal ini membahas mengenai menjamin perlindungan yang efektif terhadap lingkungan laut dari akibatakibat yang merugikan yang mungkin timbul dari kegiatankegiatan di laut, pencegahan, pengurangan dan pengendalian pencemaran dan bahaya-bahaya lainnya terhadap lingkungan laut, termasuk garis pantai, dan gangguan terhadap keseimbangan ekologis lingkungan laut dan perlindungan dan konservasi kekayaan-kekayaan alam kawasan dan pencegahan kerusakan terhadap flora dan fauna lingkungan laut. Tindakantindakan kegiatan di kawasan menjamin perlindungan terhadap lingkungan laut dari akibat-akibat yang merugikan yang mungkin timbul dari kegiatan-kegiatan tersebut yaitu

8 UNCLOS 1982 Pasal 145.

Uti Possidetis: Journal of International Law, Vol. 2, No. 1 (2021) 
pencegahan, pengurangan dan pengendalian pencemaran dan bahaya-bahaya lainnya terhadap lingkungan laut dan perlindungan terhadap kawasan konservasi. Dalam UNCLOS Pasal 192 menyatakan bahwa " Negara-negara mempunyai kewajiban untuk melindungi dan melestarikan lingkungan laut."9 Secara tidak langsung dalam konvensi ini mewajibkan negara untuk melakukan pelesatarian dan perlindungan terhadap lingkungan laut terutama terumbu karang sebagai tempat perlindungan. Kewajiban ini memberi hak kepada negara untuk melakukan pengelolaan sumber daya lingkungan laut dan mengeskplortasi sesuai dengan Pasal 193 dalam konvensi.

Tindakan-tindakan yang dilakukan guna pencemaran terumbu karang dapat mencegah, mengurangi, dan mengendalikan dilakukan dengan cara mengatur, menilai dan mengalisa kerusakan terumbu karang berdasarkan metode ilmiah mengenai resiko atau akibat dari kerusakan terumbu karang. Dalam Pasal 194 UNCLOS 1982 isinya mengenai negara harus mengambil segala tindakan yang perlu sesuai dengan konvensi untuk mencegah, mengurangi dan mengendalikan pencemaran lingkungan laut dari kegiatan laut sesuai kemampuan mereka dan negara-negara harus mengambil segala tindakan yang perlu untuk menjamin agar kegiatankegiatan yang berada dibawah yurisdiksi atau pengawasan mereka dilakukan dengan cara sedemikian rupa supaya tindakan-tindakan tersebut tidak mengakibatkan kerusakan yang disebabkan oleh pencemaran kepada negara-negara lain dan lingkungannya agar pencemaran yang timbul dari tindakan-tindakan dan kegiatan dibawah yurisdiksi atau pengawasan mereka tidak menyebar melampaui daerahdaerah yang ada di bawah pelaksanaan hak-hak kedaulatan mereka.

$9 \quad$ UNCLOS 1982 Pasal 192.

Uti Possidetis: Journal of International Law, Vol. 1, No. 2 (2020) 
Tindakan-tindakan yang dilakukan guna dapat mencegah, mengurangi, dan mengendalikan dilakukan dengan cara mengatur, menilai dan menganalisa kerusakan terumbu karang berdasarkan metode ilmiah mengenai resiko atau akibat dari kerusakan terumbu karang tesebut. Negara harus mengambil segala tindakan untuk menjamin agar kegiatankegiatan yang berada dibawah yurisdiksi mereka dilakukan agar tindakan-tindakan tersebut tidak mengakibatkan kerusakan disebabkan oleh pencemaran kepada negara-negara lain. Serta pencemaran yang timbul dari tindakan-tindakan dan kegiatan dibawah yurisdiksi mereka tidak menyebar melampaui daerah-daerah yang ada dibawah pelaksanaan hakhak kedaulatan mereka.

\section{b. Hukum Nasional}

Status kenegaraan merupakan hal pokok mengingat Negara sebagai aktor penting dalam hukum internasional. Penguasaan suatu wilayah territorial menjadi salah satu factor dari unsur status kenegaraan. Pada wilayah ini kekuasaan paling tinggi dimiliki oleh negara yang bersangkutan. ${ }^{10}$ Pembagian wilayah territorial terdiri dari wilayah darat, laut dan udara. Penentuan batas dengan Negara tetangga perlu diperjelas pada tiga wilayah territorial ini.

Beberapa pengaturan yang terkait dengan laut diatur dalam Undang-Undang Republik Indonesia. Undang-Undang No. 32 tahun 2014 Tentang Kelautan dalam Pasal 1 ayat (10) menjelaskan "Pelindungan Lingkungan Laut adalah upaya sistematis dan terpadu yang dilakukan untuk melestarikan Sumber Daya Kelautan dan mencegah terjadinya pencemaran dan/atau kerusakan lingkungan di Laut yang meliputi

10 J.G.Starke. Pengantar hukum internasional.Cetakan ke- 13. Sinar Grafika. Jakarta. 2016. hal. 210. 
konservasi Laut, pengendalian pencemaran Laut, penanggulangan bencana Kelautan, pencegahan dan penanggulangan pencemaran, serta kerusakan dan bencana."11 Dalam Pasal 1 ayat 10 menjelaskan perlindungan laut adalah upaya sistematis dan terpadu yang dilakukan untuk melestarikan Sumber Daya Kelautan dan mencegah terjadinya pencemaran atau kerusakan lingkungan di Laut. UndangUndang Nomor 32 Tahun 2009 tentang Perlindungan dan Pengelolaan Lingkungan Hidup Pasal 1 ayat (2) berbunyi:

"Perlindungan dan pengelolaan lingkungan hidup adalah upaya sistematis dan terpadu yang dilakukan untuk melestarikan fungsi lingkungan hidup dan mencegah terjadinya pencemaran dan/atau kerusakan lingkungan hidup yang meliputi perencanaan, pemanfaatan, pengendalian, pemeliharaan, pengawasan, dan penegakan hukum."12

Pasal 4 Undang-Undang Nomor 32 Tahun 2009 tentang Perlindungan dan Pengelolaan Lingkungan Hidup menyatakan "Perlindungan dan pengelolaan lingkungan hidup meliputi, perencanaan, pemanfaatan, pengendalian, pemeliharaan, pengawasan, dan penegakan hukum."13 Dalam hal ini perlindungan pengelola lingkungan hidup dengan cara perencanaan, pemanfaatan, pengendalian, pemeliharaan, pengawasan, dan penegakan hukum.

Pasal 13 Undang-Undang Nomor 32 Tahun 2009 tentang Perlindungan dan Pengelolaan Lingkungan Hidup menyatakan “ (1) Pengendalian pencemaran dan/atau kerusakan lingkungan hidup dilaksanakan dalam rangka pelestarian

11 Undang-Undang No. 32 tahun 2014 Tentang Kelautan dalam Pasal 1 ayat (10).

12 Undang-Undang Nomor 32 Tahun 2009 tentang Perlindungan dan Pengelolaan Lingkungan Hidup Pasal 1 ayat (2).

13 Undang-Undang Nomor 32 Tahun 2009 tentang Perlindungan dan Pengelolaan Lingkungan Hidup Pasal 4. 
fungsi lingkungan hidup; (2) Pengendalian pencemaran dan/atau kerusakan lingkungan hidup sebagaimana dimaksud pada ayat (1) meliputi: a. pencegahan; b. penanggulangan; dan c. pemulihan. (3) Pengendalian pencemaran dan/atau kerusakan lingkungan hidup sebagaimana dimaksud pada ayat (1) dilaksanakan oleh Pemerintah, pemerintah daerah, dan penanggung jawab usaha dan/atau kegiatan sesuai dengan kewenangan, peran, dan tanggung jawab masing-masing."14 Pasal Pasal 13 Undang-Undang Nomor 32 Tahun 2009 tentang Perlindungan dan Pengelolaan Lingkungan Hidup dalam pasal ini pengendalian pencemaran dilaksanakan dalam rangka pelestarian fungsi lingkungan hidup. Pengendalian pencemaran dilakukan dengan pencegahan, penanggulangan dan pemulihan. Pengendalian pencemaran dilaksanakan dengan dilaksanakan oleh pemerintah, pemerintah daerah, dan penanggung jawab usaha atau kegiatan sesuai dengan kewenangan, peran, dan tanggung jawab masing-masing.

Pasal 53 menyatakan setiap orang yang melakukan pencemaran wajib melakukan penanggulan serta penanggulangan yang dimaksud adalah pemberian informasi peringatan pencemaran atau kerusakan lingkungan hidup kepada masyarakat, pengisolasian pencemaran atau kerusakan lingkungan hidup, penghentian sumber pencemaran atau kerusakan lingkungan dan cara lain yang sesuai dengan perkembangan ilmu pengetahuan dan teknologi.

Perlindungan ekosistem terumbu karang di wilayah perairan Indonesia dalam undang-undang ini mengatur mengenai Pembentukan Kawasan Konservasi Laut (KKL). KKL merupakan salah satu bentuk pengelolaan sumberdaya agar terjaga kelestariannya, akibat dari kegiatan manusia. UndangUndang Nomor 5 Tahun 1990 Tentang Konservasi Sumber

14 Undang-Undang Nomor 32 Tahun 2009 tentang Perlindungan dan Pengelolaan Lingkungan Hidup Pasal 13. 
Daya Alam Hayati dan Ekosistemnya Pasal 4 berbunyi “ Konservasi sumber daya alam hayati dan ekosistemnya merupakan tanggung jawab dan kewajiban Pemerintah serta masyarakat."15 Undang-Undang Nomor 5 Tahun 1990 Tentang Konservasi Sumber Daya Alam Hayati dan Ekosistemnya Pasal 4 menyatakan " Konservasi sumber daya alam hayati dan ekosistemnya merupakan tanggung jawab dan kewajiban Pemerintah serta masyarakat. Pencegahan ini bentuk dari perlindungan kawasan konservasi dan pencegahan kerusakan lingkungan laut bertujuan pelesatarian wilayah pesisir.

\section{Pertanggungjawaban Hukum Kapal Persiar M.V. Caledonian Sky atas Kerusakan Terumbu Karang Berdasarkan UNCLOS 1982 dan Hukum Nasional.}

\section{a. Berdasarkan Hukum Internasional}

Sebagai sebuah negara kepulauan, Indonesia telah meratifikasi Konvensi UNCLOS 1982 ke dalam hukum nasional, pemerintah Indonesia telah menindaklanjutin dengan mengeluarkan peraturan perundang-undangan yaitu Undangundang No.17 Tahun 1985 Tentang Pengesahan UNCLOS 1982. UNCLOS 1982 Pasal 193 tentang hak kedaulatan negara untuk mengeksploitasikan kekayaan alamnya bahwa " Negara-negara mempunyai hak kedaulatan untuk mengeksploitasikan kekayaan alam mereka serasi dengan kebijaksanaan lingkungan mereka serta sesuai pula dengan kewajiban mereka untuk melindungi dan melestarikan lingkungan laut". ${ }^{16}$ Maka dari itu, negara memiliki hak kedaulatan untuk melakukan kewajiban melindungi dan melestarikan lingkungan laut mereka. Indonesia memiliki kewajiban melindungi dan melestarikan lingkungan laut di Raja Ampat, Papua Barat.

15 Undang-Undang Nomor 5 Tahun 1990 Tentang Konservasi Sumber Daya Alam Hayati dan Ekosistemnya Pasal 4.

16 UNCLOS 1982, Pasal 193. 
Kewajiban umum negara-negara untuk tanggung-jawab dan kewajiban ganti-rugi terdapat dalam bagian IX UNCLOS 1982 Pasal 235 yang mengatur ketentuan-ketentuan. Menyatakan:

“ (1) Negara-negara bertanggung jawab untuk pemenuhan kewajiban-kewajiban internasional mereka berkenaan dengan perlindungan dan pelestarian lingkungan laut. Mereka harus memikul kewajiban gantirugi sesuai dengan hukum internasional; (2) Negaranegara harus menjamin tersedianya upaya menurut sistem perundang-undangannya untuk diperolehnya ganti-rugi yang segera dan memadai atau bantuan lainnya bertalian dengan kerusakan yang disebabkan pencemaran lingkungan laut oleh orang perorangan atau oleh badan hukum di bawah yurisdiksi mereka; dan (3) Dengan tujuan untuk menjamin ganti-rugi yang segera dan memadai bertalian dengan segala kerugian yang disebabkan oleh pencemaran lingkungan laut, Negaranegara harus bekerjasama melaksanakan hukum internasional yang berlaku dan untuk pengembangan selanjutnya hukum internasional yang berkenaan dengan tanggung jawab dan kewajiban ganti-rugi untuk penaksiran mengenai kompensasi untuk kerusakan serta penyelesaian sengketa yang timbul, demikian pula, dimana perlu, mengembangkan kriteria dan prosedurprosedur pembayaran ganti-rugi yang memadai seperti halnya asuransi wajib atau dana kompensasi." 17

Negara-negara bertanggung jawab untuk pemenuhan kewajiban-kewajiban internasional mereka berkenan dengan perlindungan dan pelestarian terumbu karang, mereka harus memikul kewajiban ganti-rugi sesuai dengan hukum internasional. Negara-negara harus menjamin tersedianya upaya menurut sistem perundang-undangan untuk diperolehnya ganti-rugi yang segera, memadai atau bantuan lainnya yang disebabkan kerusakan terumbu karang oleh orang perorangan atau oleh badan hukum dibawah yurisdiksi

17 UNCLOS 1982 Pasal 235.

Uti Possidetis: Journal of International Law, Vol. 2, No. 1 (2021) 
mereka. Negara-negara harus menjamin tersedianya upaya menurut sistem perundang-undangannya untuk diperolehnya ganti-rugi yang segera. Selain itu, negara-negara harus bekerjasama melaksanakan hukum internasional berkenaan dengan tanggung jawab dan kewajiban ganti-rugi untuk penaksiran mengenai kompensasi atas kerusakan dan penyelesaian sengketa yang timbul serta kriteria dan prosedurprosedur pembayaran ganti-rugi.

\section{b. Hukum Nasional}

Beberapa pengaturan mengenai hukum nasional untuk kasus penabrakan kapal pesiar M.V. Caledonian Sky terhadap terumbu karang yaitu: Undang-Undang Republik Indonesia Nomor 32 Tahun 2014 Tentang Kelautan dalam Pasal 52 menyatakan:

“(1) Pencemaran laut meliputi: a. pencemaran yang berasal dari daratan; b. pencemaran yang berasal dari kegiatan di laut; dan c. pencemaran yang berasal dari kegiatan dari udara. (2) Pencemaran laut sebagaimana dimaksud pada ayat (1) dapat terjadi: a. di wilayah perairan atau wilayah yurisdiksi; b. dari luar wilayah perairan atau dari luar wilayah yurisdiksi; atau c. dari dalam wilayah perairan atau wilayah yurisdiksi ke luar wilayah yurisdiksi Indonesia. (3) Proses penyelesaian sengketa dan penerapan sanksi pencemaran laut sebagaimana dimaksud pada ayat (1) dan ayat (2) dilaksanakan berdasarkan prinsip pencemar membayar dan prinsip kehati-hatian. (4) Ketentuan lebih lanjut mengenai proses penyelesaian dan sanksi terhadap pencemaran laut dilaksanakan sesuai dengan ketentuan peraturan perundang-undangan." 18

Pasal 52 Undang-Undang Nomor 32 Tahun 2014 Tentang Kelautan menjelaskan macam-macam pencemaran laut, dapat

18 Undang-Undang Republik Indonesia No. 32 Tahun 2014 Tentang Kelautan, Pasal 52. 
terjadi di wilayah mana saja dan proses penyelesaian sengketa serta penerapan sanksi. Salah satu pencemaran yang terjadi berasal dari kegiatan di laut dan di wilayah yuridiksi Indonesia (Raja Ampat) serta proses penyelesaiannya. Proses penyelesaiannya seusai dalam pasal ini dilaksanakan berdasarkan prinsip pencemaran membayar dan prinsi kehatihatian dan ketentuan proses penyelesaian serta sanksi sesuai dengan peraturan perundang-undangan.

Pengadilan yang bertugas dalam masalah ini adalah Mahkamah Pelayaran yang dibentuk oleh dan bertanggung jawab kepada Menteri. Mahkamah Pelayaran memiliki susunan organisasi dan tata kerja yang ditetapkan dengan peraturan menteri. Mahkamah Pelayaran sebagaimana dimaksud dalam Pasal 250, memiliki fungsi untuk melaksanakan pemeriksaan lanjutan atas kecelakaan kapal dan menegakkan kode etik profesi dan kompetensi nakhoda dan/atau perwira kapal setelah dilakukan pemeriksaan pendahuluan oleh Syahbandar. ${ }^{19}$ Mahkamah pelayaran yang melakukan pemeriksaan lanjutan atas kecelakaan kapal dan menegakkan kode etik profesi dan kompetensi nakhoda atau perwira kapal setelah dilakukan pemeriksaan pendahuluan oleh Syahbandar.

Undang-Undang Nomor 32 Tahun 2009 Tentang Perlindungan Dan Pengelolaan Lingkungan Hidup Pasal 87 ayat (1) dan (2) berbunyi “ (1) Setiap penanggung jawab usaha dan/atau kegiatan yang melakukan perbuatan melanggar hukum berupa pencemaran dan/atau perusakan lingkungan hidup yang menimbulkan kerugian pada orang lain atau lingkungan hidup wajib membayar ganti rugi dan/atau melakukan tindakan tertentu;dan (2) Setiap orang yang melakukan pemindahtanganan, pengubahan sifat dan bentuk usaha, dan/atau kegiatan dari suatu badan usaha yang

19 Undang-Undang Nomor 17 Tahun 2008 Tentang Pelayaran Pasal 250 dan 251. 
melanggar hukum tidak melepaskan tanggung jawab hukum dan/atau kewajiban badan usaha tersebut."20 Maka setiap penanggung jawab kegiatan yang perbuatan melanggar hukum berupa pencemaran atau perusakan lingkungan wajib membayar ganti rugi tindakan tertentu. Dalam ayat (2) setiap kegiatan dari suatu badan hukum melanggar hukum tidak melepaskan tanggung jawab hukum atau kewajiban badan usaha tersebut.

Pemerintah Indonesia memutuskan tidak akan menuntut kapten kapal pesiar MV Calednoian Sky Keith Michael Taylor tersebut asalkan proses pertanggungjawaban dari pihak kapal pesiar M.V. Caledonian Sky terus berjalan. Noble Calidonia yang berbasis di London telah mengaku bertanggung jawab atas kerusakan itu dan mengatakan pihaknya kini berusaha menyelesaikan masalah tersebut sehingga akhirnya bisa dicapai penyelesaian yang adil dan realistis. ${ }^{21}$ Kasus ini dimungkinkan penyelesaiannya diluar pengadilan untuk mencapai kesepakatan bisa ganti-rugi, tindakan pemulihan akibat kerusakan, tindakan menjamin tidak terulang kerusakan dan tindakan mencegah timbul dampak negatif. Akan tetapi proses pertanggung jawaban atas keruskan terumbu karang belum jelas.

\section{Penutup}

Berdasarkan pembahasan diatas maka kesimpulan dari penulisan ini adalah Pertama, Perlindungan lingkungan laut terhadap kerusakan terumbu karang yang dilakukan kapal pesiar M.V. Caledonian Sky menurut hukum internasional sesuai dengan UNCLOS 1982 pasal 194 ayat (1) dan (2) mengenai tindakan-tindakan untuk mencegah, mengurangi,

20 Undang-Undang Nomor 32 Tahun 2009 Tentang Perlindungan Dan Pengelolaan Lingkungan Hidup Pasal 87 Ayat (1).

21 Tasia Masyitah, Op.Cit., hal 30. 
dan mengendalikan pencemaran lingkungan laut. Menurut hukum nasional perlindungan lingkungan laut terhadap kerusakan terumbu karang yang dilakukan kapal pesiar M.V. Caledonian Sky diatur dalam (1). Undang-Undang No. 32 Tahun 2009 Tentang Perlindungan dan Pengelolaan Lingkungan Hidup; (2). Undang-Undang No. 1 Tahun 2014 Tentang Perubahan atas Undang-undang No.27 Tahun 2007 tentang Pengelolaan Wilayah Pesisir dan Pulau-Pulau Kecil; (3). Undang-Undang Nomor 5 Tahun 1990 Tentang Konservasi Sumber Daya Alam Hayati; (4)Undang-Undang No. 45 Tahun 2009 Tentang Perubahan Atas Undang-Undang No.31 Tahun 2004 Tentang Perikanan; (5). Undang-Undang No. 32 Tahun 2014 Tentang Kelautan;dan (6). Peraturan Pemerintah (PP) Nomor 60 Tahun 2007 Tentang Konservasi Sumber Daya.

Kedua, Pertanggungjawaban Hukum Kapal Pesiar M.V. Caledonian Sky atas Kerusakan Terumbu Karang menurut hukum internasional diatur dalam UNCLOS 1982 Pasal 193 mengenai Hak kedaulatan Negara untuk mengeksploitasikan kekayaan alamnya dan Pasal 235 mengenai tanggung jawab dan kewajiban ganti-rugi. Menurut hukum nasional diatur dalam (1). Undang-Undang No. 32 Tahun 2009 Tentang Perlindungan dan Pengelolaan Lingkungan Hidup; (2). Undang-Undang No. 32 Tahun 2014 Tentang Kelautan; (3). Undang-Undang No. 1 Tahun 2014 Tentang Perubahan atas Undang-undang No.27 Tahun 2007 tentang Pengelolaan Wilayah Pesisir dan PulauPulau Kecil;dan (4). Undang-Undang No. 45 Tahun 2009 Tentang Perubahan Atas Undang-Undang No.31 Tahun 2004 Tentang Perikanan.

Artikel ini juga menyimpulkan, perusahaan Noble Calidonia yang berbasis di London telah mengakui bertanggung jawab atas kerusakan itu dan mengatakan pihaknya kini berusaha menyelesaikan masalah tersebut sehingga akhirnya bisa dicapai penyelesaian yang adil dan realistis. Kasus ini dimungkinkan penyelesaiannya diluar pengadilan untuk 
mencapai kesepakatan seperti: ganti rugi, tindakan pemulihan akibat kerusakan, tindakan menjamin tidak terulang kerusakan dan tindakan mencegah timbul dampak negatif. Penyelesaian ini merupakan realisasi asas yang ada dalam hukum lingkungan hidup yang disebut asas pencemara membayar.

\section{Referensi}

\section{Instrumen Hukum}

Republik Indonesia. Undang-Undang Tentang Konservasi Sumber Daya Alam Hayati dan Ekosistemnya. UU Nomor 5 Tahun 1990. LNRI Tahun 1990 Nomor 49.

- Undang-Undang Tentang Pelayaran. UU Nomor 17

Tahun 2008. LNRI Tahun 2008 Nomor 64. TLNRI Nomor 4849.

---------. Undang-Undang Tentang Perlindungan Dan Pengelolaan Lingkungan Hidup. UU Nomor 32 Tahun 2009 . LNRI Tahun 2009 Nomor 140. TLNRI Nomor 5059.

----------. Undang-Undang Tentang Perubahan Atas UndangUndang Nomor 31 Tahun 2004 Tentang Perikanan. UU Nomor 45 Tahun 2009. LNRI Tahun 2009 Nomor 154.TLNRI Nomor 5073.

-. Undang-Undang Tentang Perubahan Atas Undang-

Undang Nomor 27 Tahun 2007 Tentang Pengelolaan Wilayah Pesisir Dan Pulau-Pulau Kecil. UU Nomor 1 Tahun 2014. LNRI Tahun 2014 Nomor 2.TLNRI Nomor 5490.

---------. Undang-Undang Tentang Kelautan.UU Nomor 32 Tahun 2014. LNRI Tahun 2014 Nomor 294 .TLNRI Nomor 5503.

----------. Peraturan Pemerintah Tentang Hak Dan Kewajiban Kapal Dan Pesawat Udara Asing Dalam Melaksanakan 
Hak Lintas Alur Laut Kepulauan Melalui Alur Laut Kepulauan Yang Ditetapkan. PP Nomor 37 Tahun 2002. LNRI Tahun 2002 Nomor 21. TLNRI Nomor 4210.

Peraturan Pemerintah Tentang Konservasi Sumber Daya Ikan. PP Nomor 60 Tahun 2007. LNRI Tahun 2007 Nomor 134. TLNRI Nomor 4779.

Konvensi Den Haag 1930.

The Geneva Convention on Fishing and Conservation of The Living Resourcecs of The High Seas 1958(Konvensi Jenewa Perikanan dan Perlindungan Kekayaan Hayati Laut Lepas 1958).

United Nations Convention on the Law of the Sea 1982 (UNCLOS 1982).

\section{Buku}

A'an Efendi, Freddy Poernomo, IG. NG Indra S. Ranuh, Teori Hukum, Sinar Grafik, Jakarta Timur, 2017.

Aburaera Sukarno, Muhadar, Maskun, Filsafat hukum (Teori dan Praktik), Kencana, Jakarta, 2014.

Kusumaatmadja Mochtar, Perlindungan dan Pelestarian Lingkungan Laut (Dilihat dari Sudut Hukum Internasional, Regional, dan Nasional), Sinar Grafika dan Pusat Studi Wawasan Nusantara, Jakarta, 1992.

Parthiana I Wayan, Hukum Laut Internasional dan Hukum Laut Indonesia, Yrama Widya, Bandung, 2014.

Marzuki Peter Mahmud, Penelitian Hukum, Prenada Media, Jakarta, 2011.

Malcolm N. Shaw QC, Hukum Internasional, Nusa Media, Bandung, 2013.

Ramlan, Hukum Internasional, Fakultas Hukum, Universitas Jambis, Jambi, 2008. 
Sodik Didik Mohamad, Hukum Laut Internasional dan Pengaturannya di Indonesia, PT Refika Aditama, Bandung, 2014.

Sumbu Telly, Ralfie Pinasang, Frans Maramis (Filsafat Hukum), Fakultas Hukum Universitas Sam Ratulangi, Manado, 2016, hal. 22.

\section{Jurnal/Skripsi}

Citra Seftia Mardiantari, "Aspek Hukum Perlindungan Lingkungan Laut Dari Kegiatan Kapal Perikanan Di Juwana Kabupaten Pati Provinsi Jawa Tengah", Skripsi Sarjana Hukum Universitas Atma Jaya Yogyakarta, Yogyakarta, 2017.

I Wayan Restu, "Ekosistem Terumbu Karang Dan Statusnya (Studi Kasus Kondisi Terumbu Karang Di Provinsi Bali)", Program Studi Manajemen Sumberdaya Perairan Fakultas Kelautan Dan Perikanan Universitas Udayana Bali, Bali, 2016.

Panji Nugraha, "Perlindungan Terhadap Terumbu Karang dalam Pelestarian Lingkungan Hidup di Indonesia Menurut Hukum Lingkungan Internasional", Skripsi Sarjana Hukum Universitas Andalas (UNAND), Padang, 2018.

Theresia Margareth Tambunan, "Pertanggungjawaban Negara Bendera Terhadap Penahanan Kapal Ditinjau dari CONVENTION ON THE ARREST OF SHIP", Skripsi Sarjana Hukum Universitas Jambi, Jambi, 2016.

Tasia Masyitah, "Pertanggung Jawaban Kapal Caledonian Sky Atas Kerusakan Terumbu Karang Yang Berada Di Raja Ampat", Skripsi Sarjana Hukum Universitas Sumatra Utara (USU), Medan, 2018.

\section{Laman}


https://id.wikipedia.org/wiki/Hukum diakses pada Hari Rabu

Tanggal 19 Februari Tahun 2020 pada Pukul 02.45 WIB. https://id.wikipedia.org/wiki/Konvensi Perserikatan Bangsa-

Bangsa tentang Hukum Laut, diakses pada Hari Kamis

Tanggal 13 Februari Tahun 2020 Pukul 01.36 WIB.

Kamus Besar Bahasa Indonesia, https://kbbi.web.id/analisis, diakses pada Hari Rabu Tanggal 27 November 2019 Pukul 20.53 WIB.

Kamus Besar Bahasa Indonesia, https://kbbi.web.id/hukum, diakses pada Hari Rabu Tanggal 4 Maret 2020 Pukul $21.00 \mathrm{WIB}$

https://www.researchgate.net/publication/330449228 PELE

STARIAN TERUMBU KARANG DEMI KELANGSUNGAN EKOSISTEM LAUT, diakses pada Hari Selasa Tanggal 18 Februari Tahun 2020 Pukul 19.20 WIB.

https://www.academia.edu/7230224/HUKUM INTERNASION

AL - Tanggung Jawab Negara State Responsibility

diakses pada Hari Rabu Tanggal 04 Maret Tahun 2020 pada Pukul 21.00 WIB.

https://www.academia.edu/31943676/Perlindungan dan Pe

meliharaan Lingkungan Laut, diakses pada Hari Selasa

Tanggal 18 Februari Tahun 2020 pada Pukul 19.40 WIB. https://www.academia.edu/39097659/PELESTARIAN DAN P

ERLINDUNGAN PADA TERUMBU KARANG, diakses pada Hari Selasa Tanggal 18 Februari Tahun 2020 pada Pukul 23.06 WIB.

http://kkji.kp3k.kkp.go.id/index.php/basisdata-kawasan-

konservasi/details/1/64\#: : text=Raja\%20Ampat\%20 ditetapkan\%20sebagai\%20Kawasan,sebutan\%20Segit iga\%20Karang\%2FCoral\%20Triangle., diakses pada Hari Jumat Tanggal 5 Juni Tahun 2020 pada pukul 02.07 WIB

http://digilib.unila.ac.id/3574/12/BAB\%20II.pdf, diakses pada Hari Jumat Tanggal 10 Juli 2020 Pukul 23.45 WIB. 
https://kamushukum.web.id/arti-kata/hukum/, diakses pada Hari Jumat Tanggal 10 Juli 2020 Pukul 22.54 WIB.

https://www.zonareferensi.com/pengertian-analisis-

menurut-para-ahli-dan-secara-

umum/\#: : text=Menurut\%20Komaruddin\%20(2001),

dalam\%20satu\%20keseluruhan\%20yang\%20terpadu.,

diakses pada Hari sabtu Tanggal 11 Juli 2020 Pukul 01.30 WIB.

https://www.akademiasuransi.org/2012/11/hukum-laut-

internasional-dan.html, Pada Hari Selasa Tanggal 21 Juli 2020 Pukul 19.34.

https://www.voaindonesia.com/a/insiden-di-raja-ampat-

indonesia-akan-minta-pertanggungjawaban-semua-

pihak/3775111.html, diakses pada Hari Selasa Tanggal

4 Agustus 2020 pada Pukul 19.53 WIB.

https://simdos.unud.ac.id/uploads/file penelitian 1 dir/7aba

421b852c659e27c833a7550cd970.pdf, diakses pada

Hari Sabtu Tanggal 28 November Tahun 2020 pada Pukul 23.58 WIB.

https://media.neliti.com/media/publications/43170-ID-

implikasi-aliran-positivisme-terhadap-pemikiran-

hukum.pdf, diakses pada Hari Sabtu Tanggal 29

November Tahun 2020 pada Pukul 00.26 WIB

https://core.ac.uk/download/pdf/229038528.pdf, diakses

pada Hari Sabtu Tanggal 29 November Tahun 2020 pada Pukul 00.40 WIB. 